\title{
EVALUATION OF NEW SMALL-SCALE COMPOSTING PRACTICES WITH ENERGY RECOVERY
}

\author{
Roberto Guião de Souza Lima Jr. ${ }^{1}$ and Claudio Fernando Mahler ${ }^{2, *}$ \\ ${ }^{1}$ Department of Environmental Engeneering, University Center of Volta Redonda, UniFOA, Volta Redonda, Rio de Janeiro, Brazil \\ ${ }^{2}$ Department of Civil Engineering, Federal University of Rio de Janeiro, UFRJ, Rio de Janeiro, Brazil
}

Article Info:

Received:

6 June 2019

Revised:

13 February 2020

Accepted:

17 February 2020

Available online:

5 March 2020

Keywords:

Decentralized composting

Minimum impact

Energy recovery

Leachate and gas emissions

\begin{abstract}
This study involves the evaluation of new composting systems for the treatment of organic solid waste (OSW) that has low environmental impact. Two composting devices were developed, with four types of management, and their behavior was analyzed regarding temperature, gas production, moisture, leachate and percolated water production, compost maturation, nutrient presence, $\mathrm{pH}$ and water heating, which can be seen as an energy gain in addition to the economic viability of the process. The proposed composting techniques kept the waste at thermophilic temperatures for more than 20 days, with no significant emission of $\mathrm{CH}_{4}$ under aerobic conditions by passive aeration, without leachate generation. These results can be partially attributed to the suspension of the compost on pallets, the residue composition chosen in the experiments and the boundary conditions of the compartments. The energy recovery test, through water recirculation inside the compost, presented temperatures that reached $51^{\circ} \mathrm{C}$ after $24 \mathrm{~h}$ of recirculation, and were maintained throughout the process, 20 days, demonstrating its effectiveness. The proposed composting models are environmentally viable, minimizing gas emissions and leachate generation compared to landfill or industrial composting plants. They can be used in industrial kitchens, residential complexes, shopping malls and other small and medium solid waste generators. In addition, the solution presented in this study avoids the transportation of waste over medium and long distances, which also brings a significant reduction in energy expenses, and in the case of landfills, it avoids occupation for long periods, thus reducing emissions of gases and leachate, whose control and treatment are expensive.
\end{abstract}

\section{INTRODUCTION}

On site composting of organic solid waste (OSW) is an advantageous alternative to landfill disposal due to its aerobic feature, minimizing emissions by transport and degradation in the landfill, as well as leachate production and the corresponding need for treatment (Pires, Martin and Ni-Bin, 2011). However, scaling issues are relevant, as discussed by Martinez-Blanco et al. (2010) through life-cycle analysis, showing the environmental advantages of small-scale composting in comparison to industrial scale, because even predominantly aerobic composting can be a source of $\mathrm{CH}_{4}, \mathrm{NH}_{3}, \mathrm{NO}_{3}, \mathrm{~N}_{2} \mathrm{O}$ and $\mathrm{SO}_{2}$.

In this context, unwanted emissions can be minimized or avoided depending on the operation, as reported in Amlinger and Peyr Cuhls (2008), Andersen et al. (2010a), Zuokaite and Zigmontiene (2013) and Ermolaev et al. (2014). For example, home composting with higher frequency of disturbance compared to lower frequency increases GHG emissions (Andersen et al., 2010a; 2011; 2012). The same was observed by Ahn et al. (2011) with respect to $\mathrm{CH}_{4}$ in waste from a system that integrates agriculture with pasture and forest. This latter finding was a surprise, because the authors believed that the greater the number of turnings, the more aerobic the condition would be, leading to less formation of $\mathrm{CH}_{4}$.

This phenomenon can be explained by the difficulty of keeping homogeneity of the ideal environmental conditions during solid state fermentation, contributing to the formation of sites with lower oxygenation and production of $\mathrm{CH}_{4^{\prime}}$ whose release is facilitated by revolving the compost material (Durand, 2003). On the other hand, when minimizing the frequency of disturbance or operating under controlled static conditions, methanotrophic microorganisms oxidize up to $98 \%$ of the $\mathrm{CH}_{4}$ produced in the composting, as observed by Jackel, Thummes and Kampfer (2005) and Ignatius and Miller (2009). This is economically and technically viable in small-scale operations. 
Ignatius Bettio and Miller (2009a) also drew attention to emission mitigation potential and obtaining carbon credits, considering the sum of the different small-scale static composting projects. The generated organic compound also has ecological advantages over traditional chemical fertilizers (Andersen et al., 2012), adds value to the process and acts as a soil conditioner (Kiehl, 1998).

The economic difficulties and the fragility of public policies for waste management in Brazil are reflected by the fact that around $70 \%$ of municipalities still dispose of waste in dumps (IBGE, 2010). There is also a shortage of equipment appropriate for on-site treatment of OSW generated by apartment buildings, industrial kitchens, supermarkets, schools and others. In this study, we developed and tested the performance of new composter models and composting strategies with minimal impact, easy installation and operation, without proliferation of vectors or odors, focusing on the treatment of food scraps and plant trimmings. We also tested the energy use of composting for water heating, seeking to add value to the process.

\section{METHODOLOGY}

Two composter models were tested for 60 days, called 1 and 2 , using two gabions measuring $4 \mathrm{~m}$ long $x 1 \mathrm{~m}$ wide and $1 \mathrm{~m}$ high, each divided into four compartments $(A, B, C$ and $D$ ), each with volume of $1 \mathrm{~m}^{3}$ (Figure 1 ). The composters were covered with HDPE tarps to control moisture from rain and the compartments were covered on two sides by drainage mats, composed of geotextile filters, and had a three-dimensional plastic drainage core with $90 \%$ voids. The composters were also supported on pallets, increasing the passive aeration on all sides, including the base via thermal convection (chimney effect), as described in Münnich et al. (2006) and Andersen et al. (2010b). A HDPE membrane was installed below the pallets for soil protection and collection of leachates.

Composter 1 was also fitted with a drainage tube with diameter of $200 \mathrm{~mm}$ and holes along its entire length, arranged vertically in the center of each of its compartments, simulating a chimney to increase passive aeration of organic solid wastes (Figure 1).

The residues added in compartments $A, B, C$ and $D$ of each composter were inoculated as described in Table 1 and covered with a $5 \mathrm{~cm}$ layer of dried leaves after each OSW supply, to help maintain temperature and moisture as well as combat vectors such as flies.

The waste material was formulated experimentally of $33.3 \%$ food waste, $33.3 \%$ grass or leaves and $33.3 \%$ ground tree trunks (by volume), totaling approximately $500 \mathrm{~kg}$ of osW per compartment.

The composters were operated statically, without disturbance. In other words, with each new input, only the top layer of dried leaves was removed, to allow the new material to contact the material already composted.

The compartments were monitored for temperature and moisture at points 10, 25 and $50 \mathrm{~cm}$ away from the wall or 40,25 and $0 \mathrm{~cm}$ from the center and 25, 50 and 75 cm deep in each compartment, using a thermometer and Reotemp analog moisture meter with $90 \mathrm{~cm}$ rod for a total of 1.800 readings during 60 days of monitoring.
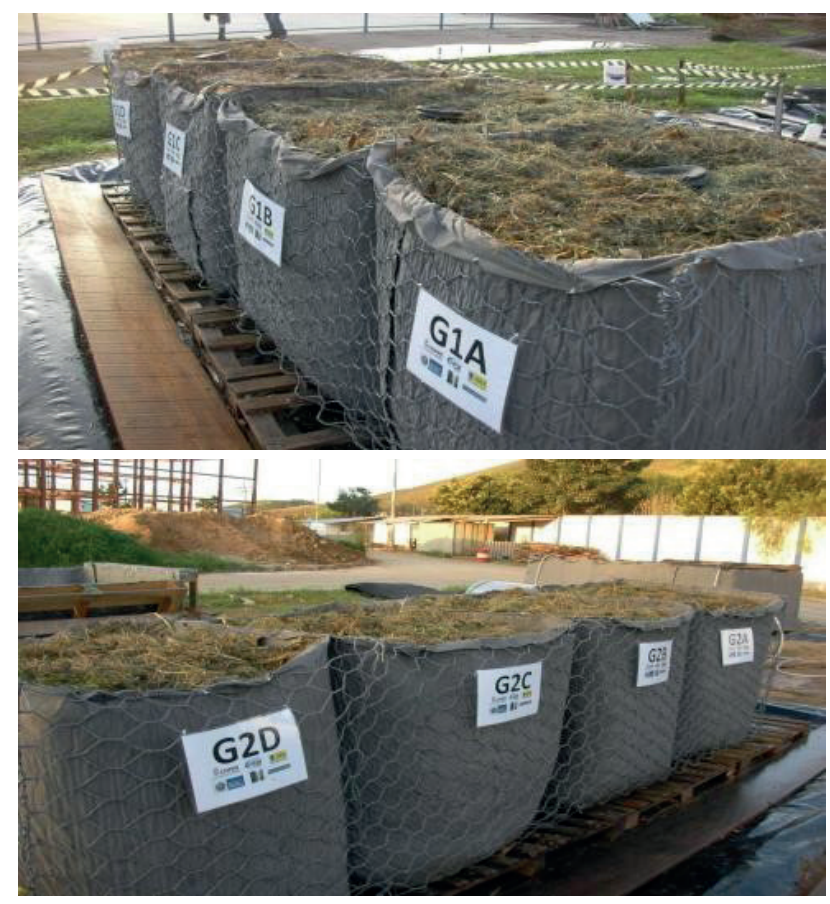

FIGURE 1: Composters 1 and 2 and their compartments A, B, C, D.

The percentages of $\mathrm{CH}_{4}$ and $\mathrm{O}_{2}$ gases were measured at 10,25 and $50 \mathrm{~cm}$ from the wall or 40,25 and $0 \mathrm{~cm}$ from the center and 30 and $60 \mathrm{~cm}$ depth in each compartment, using a Dräger X-AM7000 gas analyzer connected to a 1 meter metal rod (1,200 readings).

The same gas analyzer was used to determine the emissions from each compartment, associated with an Agilent Technologies model ADM200 flowmeter and a pyramidal flow chamber, covering the entire surface area of each compartment, as described in Andersen et al. (2010a).

The data were grouped into treatment pairs, considering the mean values of compartments $A, B, C$ and $D$ of composters 1 and 2, namely, $1 \mathrm{~A}$ and $2 \mathrm{~A}, 1 \mathrm{~B}$ and $2 \mathrm{~B}, 1 \mathrm{C}$ and $2 C$, and $1 D$ and $2 D$. These were treated as repetitions since the differences between composters 1 and 2 concerning the presence of the central aeration (composter 1 only) were the same for all four treatments, henceforth simply called compartments $A, B, C$ and D. Data were also evaluated considering composter 1 and 2 individually to identify variations between them, comprising the averages of data obtained from compartments $A, B, C$ and $D$ of each composter together, since the differences between these

TABLE 1: Management strategies of the compartments.

\begin{tabular}{|c|c|}
\hline Compartments & Inoculation Strategy \\
\hline A & $\begin{array}{l}\text { OSW inoculated with } 10 \% \text { of its volume of compost } \\
\text { after each input. }\end{array}$ \\
\hline B & $\begin{array}{l}\text { OSW inoculated with } 10 \% \text { of its volume of compost } \\
\text { in the first input. }\end{array}$ \\
\hline C & $\begin{array}{l}\text { OSW inoculated with } 10 \% \text { of its wet weight with liquid } \\
\text { inoculum } E M(\text { in every contribution }(E M \cap \text { : lactic acid } \\
\text { bacteria, phototrophic bacteria and yeasts). }\end{array}$ \\
\hline $\mathrm{D}$ & $\begin{array}{l}\text { Control compartment receiving OSW without external } \\
\text { inoculant. }\end{array}$ \\
\hline
\end{tabular}


compartments were also common to both composters. The $\mathrm{pH}$, carbon/nitrogen ratio $(\mathrm{C} / \mathrm{N})$ and nutrients $\mathrm{P}, \mathrm{K}, \mathrm{Na}$ and $\mathrm{Mg}$ in the waste before intake and after 60 days of composting were evaluated, in duplicate samples, following the methods described in Andrade and Abreu (2006). Leachate generated in composters 1 and 2, independent of the compartment, was evaluated for $\mathrm{pH}$ and $\mathrm{COD}$ after 60 days, with samples in duplicate, following the Standard Methods D520 (Standard Methods, 1997).

Comparisons between the above parameters were made by analysis of variance (ANOVA) at a significance level of $95 \%$, with prior verification of normality and homoscedasticity of the variables, as suggested by Sokal and Rohlf (2012). Since most of the data did not meet these requirements, we used base-ten logarithmic transformation [Log $(x+1)]$ prior to ANOVA, followed by the Tukey test to compare the means, at 95\% confidence level $(p<0.05)$.

Data on variations of depth and distance from the wall of the compartments were analyzed separately for all compartments and composters, for a better understanding of their behavior considering the differences between treatments and composters.

To test the energy use for water heating, a composter with total volume of $2 \mathrm{~m}^{3}$ was used. Two waste compositions were studied, expressed in volume: (i) composition: $33.3 \%$ food waste, $33.3 \%$ grass and leaves (dry and green) and $33.3 \%$ ground trunks; (ii) composition: $50 \%$ ground trunks and $50 \%$ green grass.

This composter was equipped with a $44 \mathrm{~m}$ copper coil with diameter of $12.70 \mathrm{~mm}$, immersed in the OSW to a depth of $50 \mathrm{~cm}$ from the bottom, through which 300 liters of water was circulated by an electric pump 24 hours after the intake of OSW, between the composter and a boiler with thermal insulation. The temperature was measured outside (air temperature) and at the water outlet of the composter.

\section{RESULTS AND DISCUSSION}

\subsection{Temperature}

Compartments A, B, C and D exhibited average temper- atures that were mesophilic and reached maximums that were thermophilic, close to $70^{\circ} \mathrm{C}$ (Figure 2a), which were maintained for more than 20 consecutive days, enough for waste hygiene (USEPA, 1992). Significantly lower temperatures were observed in compartments $A$ compared to $C$ and $D$, which may have been caused by the $10 \%$ compost added as inoculum in these compartments, lowering their temperature to improve the porosity and consequently the oxygenation of OSW, in the same manner as observed in soils, where the addition of compost favors the formation of granules (Kiehl, 1998).

Among the composters, significantly higher temperatures were observed in composter 2 (Figure $2 b$ ), attributed to the absence of a central chimney.

Inside composter 1's compartments, the highest temperatures were observed $25 \mathrm{~cm}$ away from the wall or 25 $\mathrm{cm}$ from the center, against $50 \mathrm{~cm}$ in the compartments of composter 2 , showing the influence of the chimney present in compartments 1 as a differential element with respect to passive cooling. In vertical evaluation, there was a common pattern in the compartments of composters 1 and 2 regarding the highest average temperature at $25 \mathrm{~cm}$ depth, compared to 50 and $75 \mathrm{~cm}$. This result is probably related to the positioning of the composters on pallets, in contrast to traditional layouts, as noted by Jackel, Thummes and Kampfer (2005) and Ignatius et al. (2009b). This design helps establishment of the chimney effect and consequent redistribution of heat by the system, positively influencing the passive oxygenation and minimizing the formation of anaerobic sites, which result in the generation of $\mathrm{CH}_{4}$ and leachate (Münnich et al., 2006) (Figure 3).

\subsection{Gases}

The percentage of $\mathrm{CH}_{4}$ was between 0.0 and $2.6 \%$ in the waste, with the highest average being lower than $0.2 \%$ in treatment $\mathrm{D}$ (Figure 4a). This minimization of $\mathrm{CH}_{4}$ generation contrasts with the findings of Ignatius et al. (2009b), who studied composters with sizes, OSW composition and input regimes very similar to those of the present study. They found an average value of up to $15 \% \mathrm{CH}_{4}$ in central areas of their compost piles, about 6 times more than
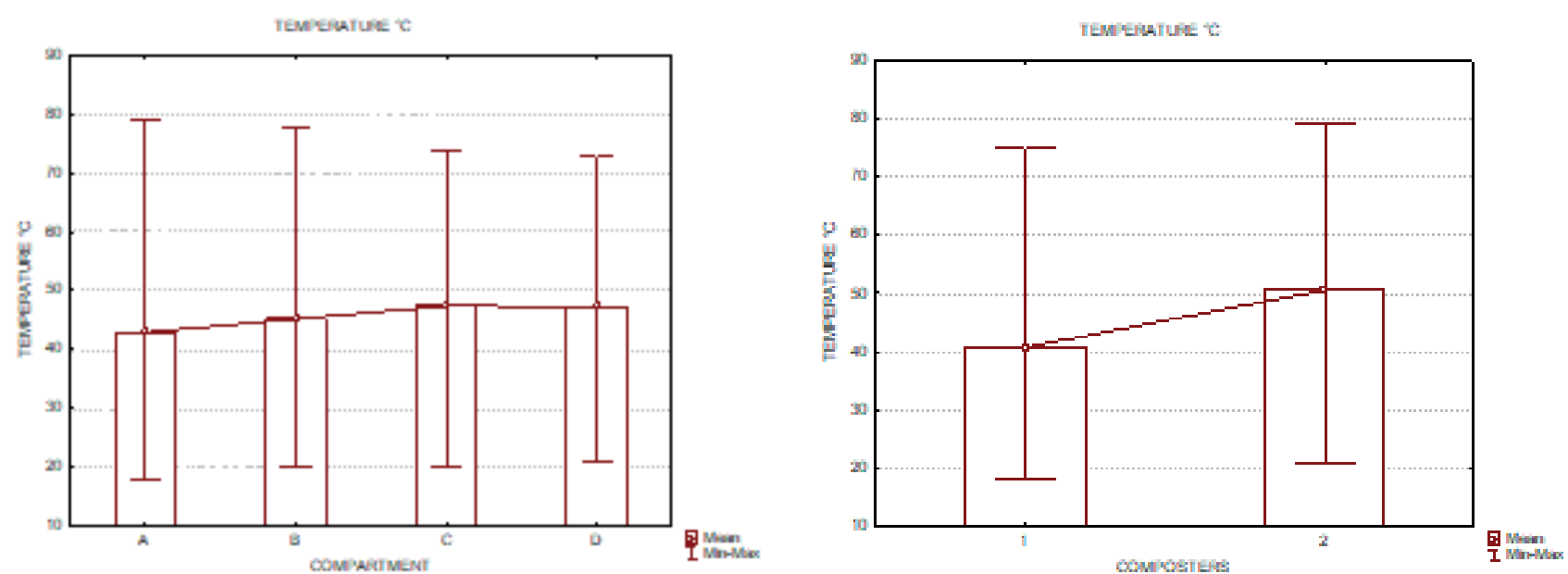

FIGURE 2a/2b: Average, minimum and maximum temperature per compartment and composter, respectively, in ${ }^{\circ} \mathrm{C}$. 

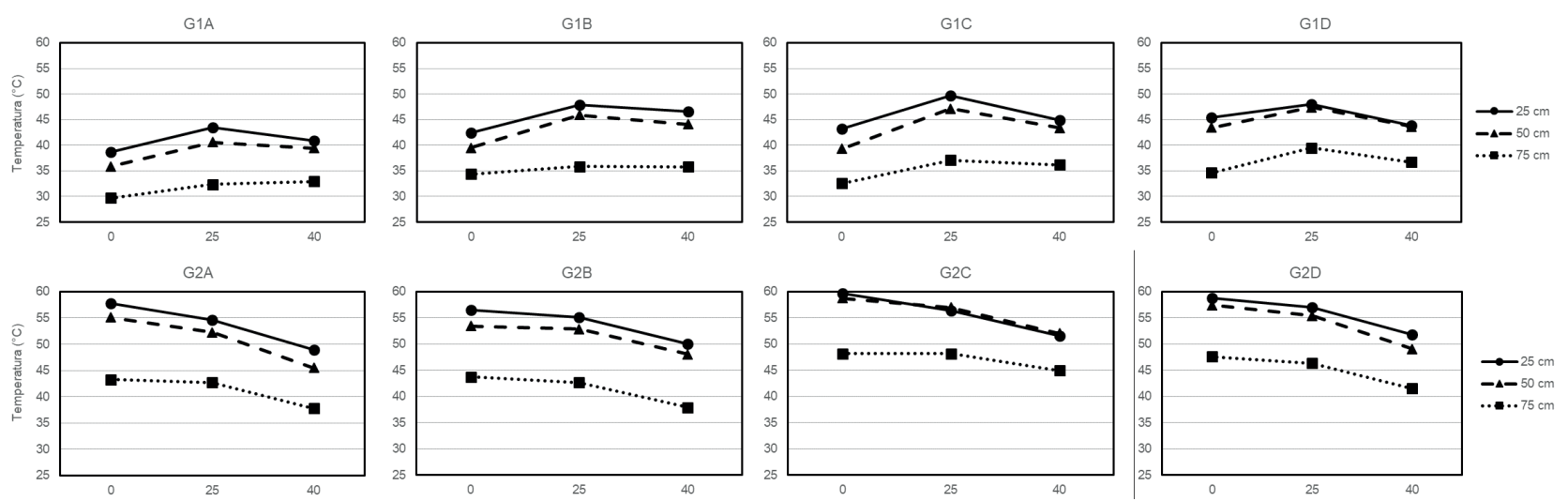

FIGURE 3: Average temperature in ${ }^{\circ} \mathrm{C}$ within the compartments 40,25 and $0 \mathrm{~cm}$ from the center, and 25,50 and $75 \mathrm{~cm}$ depth.

the highest maximum result in the central areas of this study. This positive result can be related to the efficient passive aeration, the result of the adopted materials and management strategies, ensuring aerobic conditions in all compartments, even those without chimney, since the generation of $\mathrm{CH}_{4}$ is directly related to the establishment of anaerobic conditions in the OSW (Munnich et al., 2006), usually related to high moisture and low penetration of $\mathrm{O}_{2}$ (Jiang et al., 2011; Kiehl, 1998).

However, even with little generation of $\mathrm{CH}_{4}$, we observed significantly lower percentage of the gas in treatment $A$ compared to $C$ and $D$. This can be attributed to the addition of compost in maturation as inoculum at each input in treatment $A$, suggesting the efficiency of micro methanotrophic organisms present in the OSW to colonize and oxidize the $\mathrm{CH}_{4}$ produced. This was also noted by Jackel, Thummes and Kampfer (2005) and Rose et al. (2012), investigating minimization of $\mathrm{CH}_{4}$ emissions in composting and landfills with final compost coverage.

Regarding composters, both generated low percentages of $\mathrm{CH}_{4}$ (Figure 4b), although composter 1 showed significantly lower values than composter 2 . This can be attributed to increased oxygenation and predominance of mesophilic temperatures in 1 , since methanogenic microorganisms grow best at thermophilic temperatures and methanotrophic ones find better conditions for growth and $\mathrm{CH}_{4}$ oxidation at mesophilic temperatures (Jackel et al., 2005).

Horizontally, within composter 1 the highest average $\mathrm{CH}_{4}$ values were observed in the waste $25 \mathrm{~cm}$ from the center of the composter, due to the central aeration of these compartments. In composter 2, without central aeration, the highest percentages of $\mathrm{CH}_{4}$ predominated at the center of the composter. Variations in $\mathrm{CH}_{4}$ according to depth did not exhibit a characteristic pattern, with larger values changing between 30 and $60 \mathrm{~cm}$ deep, although higher values predominated at $60 \mathrm{~cm}$ (Figure 5).

$\mathrm{CH}_{4}$ emissions were sparse and minimal in all measurements, close to the minimum detection limit of $0.01 \%$, and $5 \%$ reading error of the gas analyzer used. So, since all treatments proved to be effective in minimizing the production of $\mathrm{CH}_{4}$ and/or metabolizing the gas, we considered the emissions from all compartments to be negligible. This finding is similar to those reported by Jackel at al. (2005) and Ignatius et al. (2009b), where up to $98 \%$ of the produced $\mathrm{CH}_{4}$ was oxidized by methanotrophic communities. Further corroborating this assumption is that the average temperatures varied between 40 and $50^{\circ} \mathrm{C}$ in all compartments, the optimal range for activity of methanotrophic microorganisms, as already discussed. Thus, considering
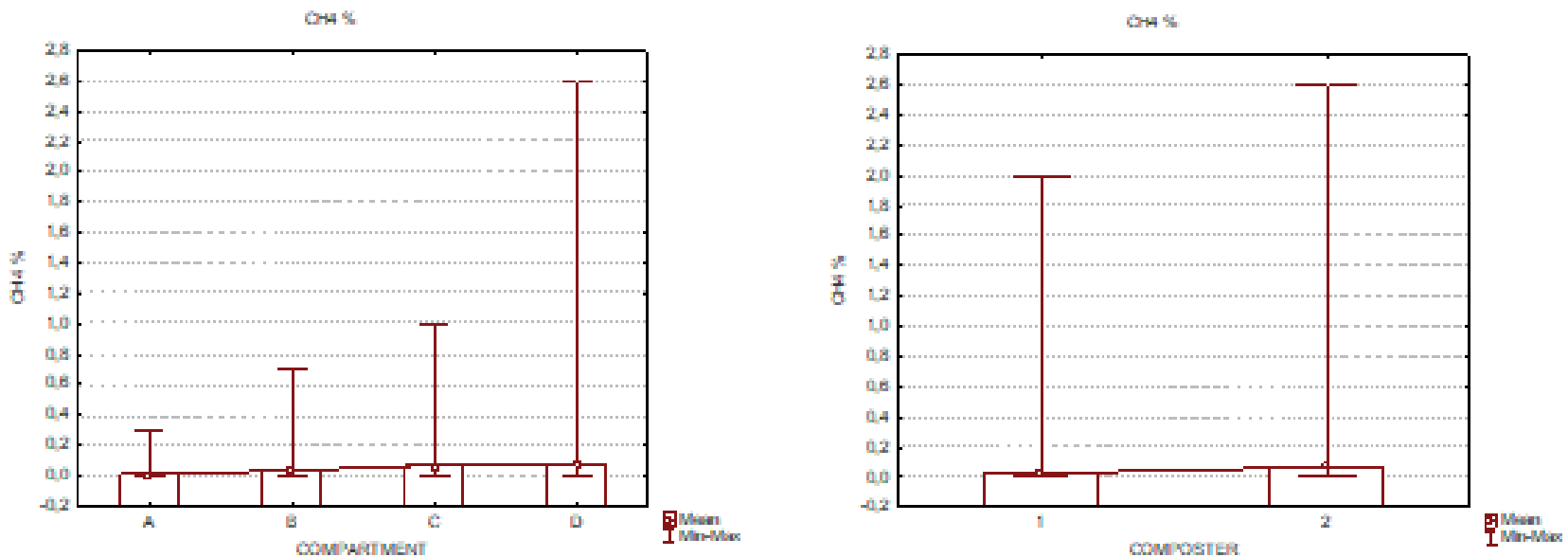

FIGURE 4a/4b: Maximum, minimum and average percentage of $\mathrm{CH}_{4}$ by compartment and composter, respectively. 


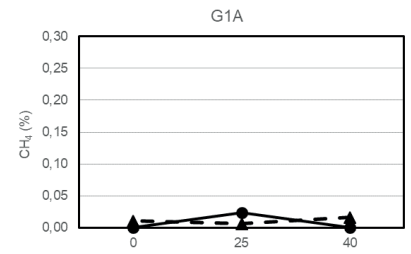

G2A

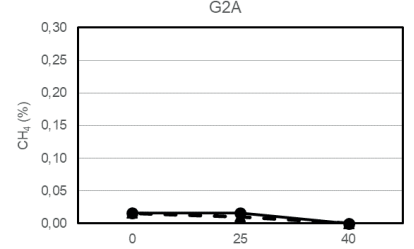

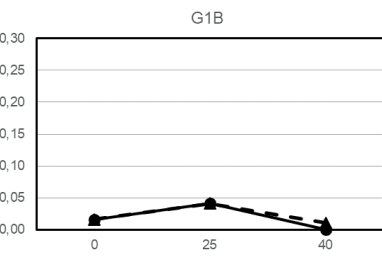

$\mathrm{G} 2 \mathrm{~B}$

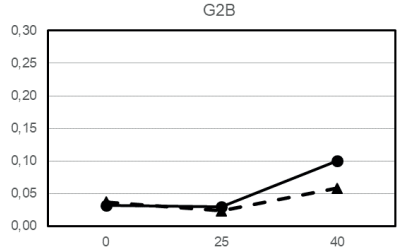

G1C

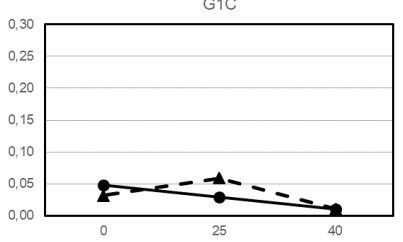

$\mathrm{G} 2 \mathrm{C}$

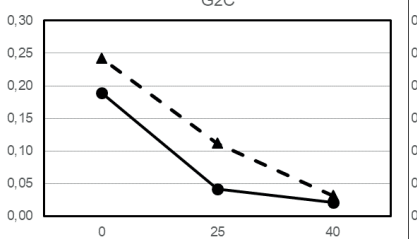

G1D

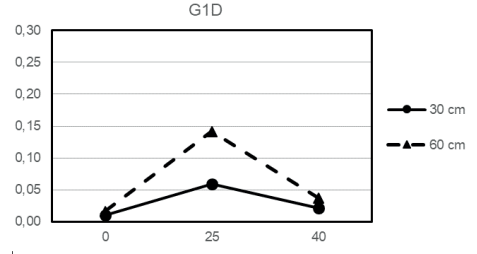

G2D

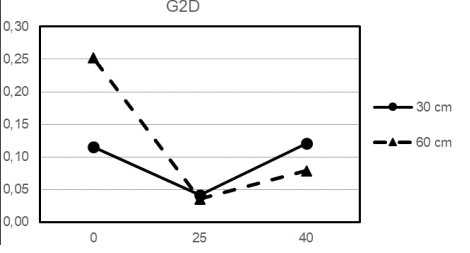

FIGURE 5: Average percentage of $\mathrm{CH}_{4}$ at 40, 25 and $0 \mathrm{~cm}$ from the center, and 30 and $60 \mathrm{~cm}$ depth.

the emission of $600 \mathrm{~kg}$ of $\mathrm{CO}_{2}$ eq./metric ton of ground OSW (USEPA, 2005), the 4 tons of OSW composted in this experiment avoided the emission of 2.4 tons $\mathrm{CO}_{2}$ eq.. Furthermore, the absence of the need to transport the waste to a landfill prevented the emission of $87 \mathrm{~kg}$ of $\mathrm{CO}_{2}$ eq., considering the emission of $2.9 \mathrm{~kg} \mathrm{CO} / \mathrm{I}$ of diesel oil and the consumption of $7.5 \mathrm{~L}$ of diesel oil per ton of transported waste (Mahler, 2012). When discounting emissions that could theoretically be avoided in landfills by capture, burning and/or use for energy generation of $\mathrm{CH}_{4}$, and assuming maximum efficiency between $30 \%$ and $40 \%$ of emissions avoided, as observed by Viana (2011) and Maciel and Juca (2011), respectively, the emissions avoided by on-site composting would diminish by $34 \%$.

Many aspects contribute together to minimize the generation of $\mathrm{CH}_{4}$ from composting. Size, density, input intensity and presence of methanotrophic microorganisms are the most relevant parameters (Jackel et al, 2005). They are directly related to the oxygenation and temperature of the system and inversely proportional to the variation of the generation of $\mathrm{CH}_{4}$.

Since the present study investigated static operation, we believe the combination of a high proportion of structuring material and the positioning of the composters on pallets were important, by helping to establish efficient passive aeration, as evidenced by the mean $\mathrm{O}_{2}$ between 17 and $20 \%$ among compartments and composters (Figures $6 \mathrm{a}$ and $6 \mathrm{~b}$ ). These values were sufficient to ensure that all treatments presented suitable aerobic conditions in the composting process, defined as above $5 \% \mathrm{O}_{2}$ by Kiehl (1998) and above $10 \%$ by Miller (1993).

However, the solid organic waste present in treatments $A$ and $B$ exhibited significantly higher average 02 percentages than in treatments $C$ and $D$. This can be attributed to addition of compost as inoculum, which assists entry of $\mathrm{O} 2$ by increasing the porosity of the waste, especially in treatment $A$, as discussed in the item on temperature.

In static windrow piles, the $\mathrm{O} 2$ concentration also depends on the intensity of consumption by microorganisms and their replacement via passive aeration, which is influenced by the porosity of the material in the pile, moisture and the internal heat (Randle and Flegg, 1978). In this regard, it is noteworthy that the lowest average temperature and the highest average percentage of $\mathrm{O}_{2}$ were observed in compartment $1 \mathrm{~A}$, which to some extent minimized the influence of temperature difference with respect to increased passive aeration and maximized the influence of possible increase in the porosity of the OSW due to the use of compost as inoculum. Also confirming the influence of the compost on the oxygenation of OSW is the fact that
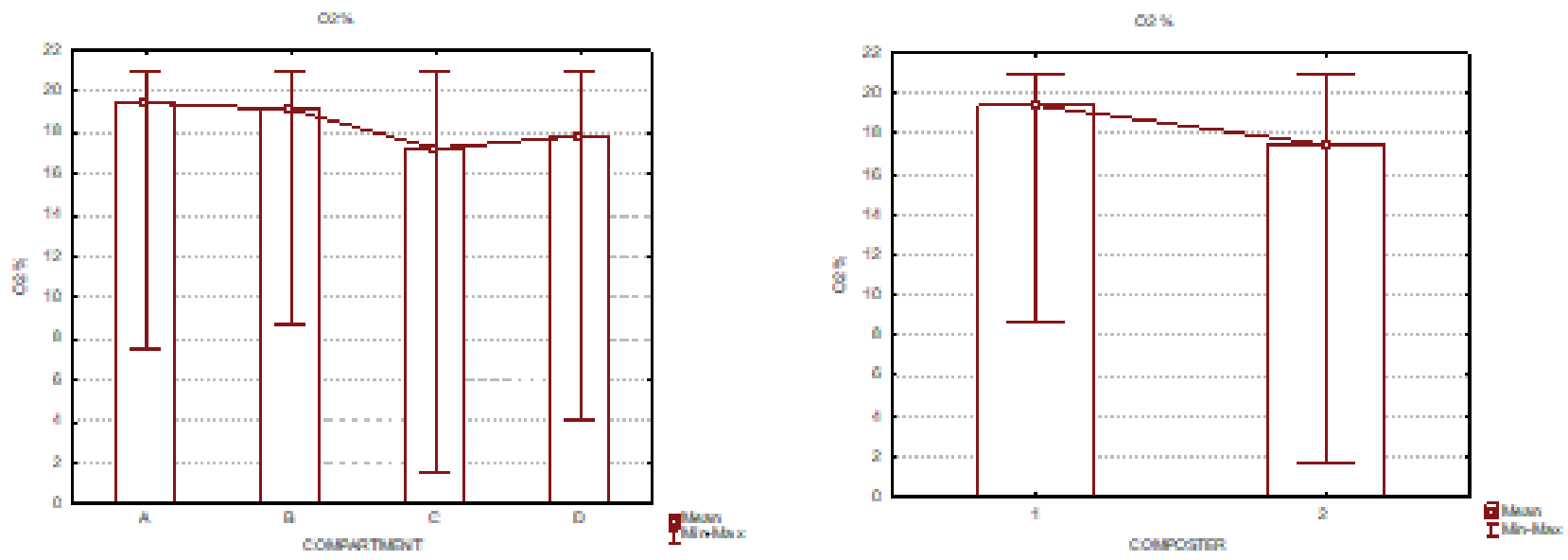

FIGURE 6a/6b: Maximum, minimum and average percentage of $\mathrm{O}_{2}$ by compartment and composter, respectively. 
compartment $2 \mathrm{~A}$, without chimney and inoculated with compost, presented an average $\mathrm{O}_{2}$ value compatible with those observed in compartments $1 \mathrm{C}$ and 1D, equipped with central chimney, despite the higher moisture in $2 \mathrm{~A}$.

Between composters, higher $\mathrm{O}_{2}$ percentage was expected in composter 1 , due to the presence of the central chimney, facilitating oxygenation and moisture loss. This effect is supported by the higher moisture observed in composter 2 , which is discussed below.

\subsection{Moisture}

Taking all the compartments together, the average moisture was near $60 \%$, with significantly smaller differences for treatment A compared to the other treatments. This can be attributed to the use of compost as inoculum, since the increase in oxygenation attributed to the presence of compost favored drying even with the lower temperatures observed in $A$ in comparison with the other treatments. Between the composters, the lowest average moisture in the waste was observed in composter 1 , about $50 \%$, versus about $70 \%$ in composter 2 , attributed to the central aeration in composter 1 .

Thus, the average moisture levels in the compartments and composters were between the minimum and maximum levels considered ideal for composting, of 50 and $70 \%$, as suggested by Jiang et al. (2011), Kiehl (1998) and Brazil (2009), indicating proper maintenance of this parameter. Composting with moisture above $70 \%$ reduces 02 by excess water in waste macropores, while moisture below $50 \%$ reduces microbial activity, which ceases entirely below around 40\% (Kiehl, 1998).

From an environmental point of view, Jiang et al. (2011) suggested that $65 \%$ moisture is the optimal value to minimize GHG emissions, the closest value to those attained by treatments $B, C$ and $D$ and composter 2, although compartment $A$ in composter 2 was closest to $65 \%$ moisture.

It is noteworthy that the B compartments, although not differing in moisture significantly in relation to $C$ and $D$, achieved significantly better performance with respect to $\mathrm{O} 2$ than $\mathrm{C}$ and $\mathrm{D}$, similar to the $\mathrm{A}$ compartments. This aspect confirms again the importance of the type of inoculation applied to the compost mass regarding the adequacy of environmental parameters.

\subsection{Leachate and percolated water}

There was no generation of leachate in the composters and only a small amount of percolated water was produced, resulting from the external supply of water for wetting the compartments. This characteristic is attributed to the same aspects of maintenance of aerobic conditions discussed above, since the generation of leachate and $\mathrm{CH}_{4}$ is directly related to the establishment of anaerobic conditions (Munnich at al., 2006).

The leachates generated presented average COD of $116.5 \mathrm{mg} \mathrm{L}^{-1}$, so they were suitable for reuse to wet the composters or as liquid fertilizer. They could also be discarded, considering that according to the average COD/ BOD ratio of $2 / 1$, suggested by Jordan and Person (2005), the average value of DBO for the leachate in question would be $55.5 \mathrm{mg} \mathrm{L-1}$, meeting the effluent discharge standards set by CONAMA (2005) for BOD of up to $60 \mathrm{mg} \mathrm{l}-1$ (there are no limits for wastewater discharge based on COD in Brazilian federal regulations).

Such COD values contrast with $9,870 \mathrm{mg} \mathrm{L}^{-1}$ obtained in traditional residential composting (Andersen et al., 2011). Obviously, such differences are understandable, since the comparison is between percolated water from wetting compost piles and leachate.

The average $\mathrm{pH}$ values of the leachate from composters 1 and 2, after 60 days, were 7.1 and 7, respectively, meeting the $\mathrm{pH}$ limit for disposal of waste according to CONAMA (2005).

\subsection{Maturation of the compost}

The $\mathrm{C} / \mathrm{N}$ ratio $<20$ is an indicator of stability for organic fertilizer class C according to Brasil (2009). In this regard, most of the treatments had $\mathrm{C} / \mathrm{N}$ ratio indicating stability after 60 days, except for the $\mathrm{D}$ compartments, where the $\mathrm{C} / \mathrm{N}$ averaged nearly 21 , significantly smaller than $D$, suggesting the advantage of inoculation with compost with respect to degradation of organic solid wastes.

Between the composters, both had $\mathrm{C} / \mathrm{N}<20$, indicating stability of the material after 60 days. But composter 1 had $\mathrm{C} / \mathrm{N}$ ratio significantly higher than composter 2 , a result which may have been influenced by higher temperatures reached in composter 2 . The average initial value of the $\mathrm{C} / \mathrm{N}$ ratio of fresh OSW was $26 / 1$.

\section{$3.6 \mathrm{pH}$}

The $\mathrm{pH}$ of the wastes from treatments $\mathrm{A}, \mathrm{B}$ and $\mathrm{C}$, which received no inoculum, reached average values higher than 7 after 60 days, which was not observed in $\mathrm{D}$, with $\mathrm{pH}$ below neutral (see Table 2). This aspect suggests composting without addition of inoculum is slower, although usually this process demands 90 to 120 days (Kiehl, 1998).

Treatment A presented significantly higher $\mathrm{pH}$ than $\mathrm{C}$ and $D$, which reinforces the idea that adding inoculum improves compost maturation.

However, residues in all compartments reached the reference value of $\mathrm{pH}>6.5$, described in Brasil (2009) and Giró (1994), suggesting that the material could complete its process of degradation in contact with the ground.

Both composters reached neutral pH after 60 days, with no significant differences, indicating that the differences in the temperature and oxygenation, derived from their mor-

TABLE 2: $\mathrm{pH}$ of OSW (before composting) and after 60 days of composting.

\begin{tabular}{c|c} 
Sample & pH \\
Fresh OSW & 5.6 \\
\hline Compartment A & 7.5 \\
\hline Compartment B & 7.3 \\
\hline Compartment C & 7.1 \\
\hline Compartment D & 6.7 \\
\hline References & $<6.5 \mathrm{a}$ \\
\hline & $6.5 / 8 \mathrm{~b}$ \\
\hline
\end{tabular}

References: a) Brasil (2009), organic fertilizer from municipal solid waste; b) Giró (1994), mixed organic waste (public parks, gardens and homes) 
phology (presence or absence of central chimney) did not affect the $\mathrm{pH}$ value.

\subsection{Vectors}

All treatments were effective in preventing the proliferation of flies and mice, a fact related to the maintenance of thermophilic temperatures, management strategy based on periodic OSW input and daily coverage with dry material, as suggested by Ignatius and Miller (2009). However, composter 2 was more efficient than 1 in combating flies, probably due to the higher temperatures. Particularly noteworthy is compartment $2 \mathrm{~A}$, which remained completely free of flies. This may be related to the use of compost every contribution, also suggesting its effectiveness in minimizing odors that attract vectors.

\subsection{Water heating}

The use of composting for heating water was appropriate because the 300 liters of water recirculated through the OSW reached $51^{\circ} \mathrm{C}$ after $24 \mathrm{~h}$ and remained at this temperature for 8 consecutive days in composter 1 , with average ambient temperature of $21^{\circ} \mathrm{C}$ and maximum temperature of $71^{\circ} \mathrm{C}$ inside the composter. In composter 2 , the same volume of water reached a temperature of $42^{\circ} \mathrm{C}$ after 24 hours in circulation and remained at that temperature for 15 consecutive days, with a mean ambient temperature of $23^{\circ} \mathrm{C}$ and maximum temperature of $62^{\circ} \mathrm{C}$ inside the composter.

However, the recirculation strategy depended on energy for pumping water and use of composter 1 would require frequent load changes. On the other hand, Jean Pain (1972) and Native Power (2013) suggested the passage of water only once through OSW, in long plastic hoses, and the use only of shredded trunks due to the longer degradation time of this material, (up to six months), which cheapens and facilitates the implementation of such systems, known in Germany as "Biomeiler".

\section{CONCLUSIONS}

Two composting devices were developed, with four different types of management in each, and their behavior was studied regarding temperature, gas production, moisture, leachate and percolated water production, compost maturation, nutrient presence, $\mathrm{pH}$. and water heating.

Both composters and all four treatments studied were effective considering health and environmental aspects, more so for composter 2 (without central chimney) and treatment $A$ ( $10 \%$ compost added) (see Table 1$)$ in relation to combatting vectors and degradation of OSW as well as for neutralization of $\mathrm{CH} 4$ more efficiently, suggesting the use of model $2 \mathrm{~A}$ in practical applications.

Overall, the maturation of the compound was satisfactory, with a $\mathrm{C} / \mathrm{N}$ ratio $<20$ in almost all cases, indicating system stability after 60 days.

As for the $\mathrm{pH}$, in all compost neutral values were reached after 60 days. In addition, the composters did not attract vectors, such as flies and mice.

The eight studied cases of composters reached temperatures of up to almost $80^{\circ} \mathrm{C}$ in some cases, and had negligible $\mathrm{CH}_{4}$ gas emission and release of leachate and percolated water.

There were no oxygen deficiencies in composter 2, making it unnecessary to use central aeration.

The good results of the experiments can be attributed mainly to the suspension of composters on pallets, the waste composition and boundary conditions adopted.

The energy recovery process showed that the water heating worked very well, reaching temperatures up to $51^{\circ} \mathrm{C}$ after $24 \mathrm{~h}$ of recirculation, for long periods, more than 20 days, with temperatures near $70^{\circ} \mathrm{C}$, showing that this process can be a potential energy source.

The proposed composting model is environmentally feasible, because it minimizes gas emission and leachate generation compared to the landfill deposition or industrial composting plants.

\section{ACKNOWLED GMENTS}

The authors would like to thank CAPES, CNPq, FAPERJ and UNIFOA for supporting this study.

\section{REFERENCES}

Ahn, H.K.; Mulbry, W.; White, J.W.; Kondrad, S.I. Pile mixing increases greenhouse gas emissions during composting of dairy manure. Bioresource Technology, v.102, 2011, p. 2904-2909.

Amlinger, F.; Peyr, S.; Cuhls, C. Green house gas emissions from composting and mechanical biological treatment. Waste Management e Research, v.26, 2008, p. 47-60.

Andersen, J. K.; Boldrin, A.; Christensen, T. H.; Scheutz, C. Greenhouse gas emissions from home composting of organic household waste. Waste Management, v. 30, n,12, 2010a, p.2475-2482.

Andersen, J. K.; Boldrin, A.; Christensen, T. H.; Scheutz, C. Quantification of greenhouse gas emission from windrow composting of garden waste. Journal of Environmental Quality, v.39, 2010b, p.713-724.

Andersen, J. K.; Boldrin, A.; Christensen, T. H.; SCHEUTZ, C. Mass balance and life cycle inventory of home composting of organic waste. Waste Management, v.31, n. 9-10, 2011, p.1934-1943.

Andersen, J.K.; Boldrin, A.; Christensen, T. H.; Scheutz, C. Home composting as an alternative treatment option for organic household waste in Denmark: An environmental assessment using life cycle assessment-modelling. Waste Management, v.32, n.1, 2012, p.3140.

Andrade, J.C.; Abreu, M.; Falcão, A.A. Protocols of Chemical Analysis. Chemical analysis of solid waste for monitoring and agro-environmental studies. Agronomic Institute, Campinas, 2006, p.121-158. (in Portuguese)

Brasil. Ministry of Agriculture, Livestock and Supply of Agricultural Defense Secretariat, n.d. Normative Instruction No. 25 of 23 July 2009. Available at:<http://sistemasweb.agricultura.gov.br/sislegis/action/detalhaAto.do?method=consulttarLegislacaoFederal>. Access: 28 November 2014. (in Portuguese)

CONAMA. Ministry of Environment, 2005. CONAMA No 357 of 17 March 2005. Available at: <http://www.mma.gov.br/port/conama/ res/res05/res35705.pdf>. Accessed on: 22 Mar. 2014. (in Portuguese)

Durand, A. Bioreactor designs for solid state fermentation. Biochemical Engineering Journal, v.13, n. 2-3, 2003, p.113-125.

EM® (2012). Efficient Microorganism. Available at: <http://www.em-la. com>. Accessed on 10 May 2012.

Ermolaev, E.; Sundberg, C.; Pell, M.; Håkan, J. Greenhouse gas emissions from home composting in practice. Bioresource Technology, v.151, 2014, p.174-182.

Giró F. Qualitat proposed legislation to composted per municipals to Residus Catalunya (in Catalan). Residus Board. Generalit at de Catalunya; 1994. (in Spain)

IBGE - Brazilian Institute of Geography and Statistics. (2010) Census 2010 Rio de Janeiro: IBGE. Available at: <www.ibge.gov.br>. Access: 10 April 2013. 
Inácio, C. T .; Bettio, D. B .; Miller, P. R. mitigation potential of methane emissions through composting projects on a small scale. In: Brazilian Congress of Organic Waste. Anais ... Victory: SBCS, 2009a. CD ROM. (in Portuguese)

Inácio, C. T.; Procópio, A. S.; Teixeira, C.; Miller, P. R. O dynamics, $\mathrm{CO} 2$ and $\mathrm{CH} 4$ in static windrow composting during the thermophilic phase. In: Brazilian Congress of Organic Waste. Anais ... Victory: SBCS, 2009b. CD ROM. (in Portuguese)

Inácio, C. T.; Miller, P. R. Composting, science and practice for organic waste management. 1st ed. Rio de Janeiro: Embrapa Solos, 2009. 156p. (in Portuguese)

Jackel, U.; Thummes, K.; Kampfer, P. Thermophilic methane production and oxidation in compost. FEMS Microbiol. Ecolgy, v.52, n. 2, 2005, p. 175-184.

Jiang, T.; Schuchardt, F.; Li, G.; Guo, R.; Zhao, Y. Effect of C/N rate and moisture conten on ammonia and greenhouse gas emission during the compost. Journal of Environmental Sciences, v.23, n. 10 , 2011, p.1754-1760.

Jordão, E. P.; Pessoa, C. A. Domestic sewage treatment. 4 ed. Rio de Janeiro: Ed. ABES, 2005. 932p. (in Portuguese)

Kiehl, E. J. Composting Manual: Maturation and Compost Quality. 4th ed. Piracicaba: Ed. Edmar José Kiehl, 1998. 171p. (in Portuguese)

Maciel, F. J., Jucá, J. F. T. Evaluation of landfill gas production and emissions in a MSW large-scale Experimental Cell in Brazil. Waste Management v.31, p. 966-977, 2011.

Mahler, C.f. Urban waste. 1 ed. Rio de Janeiro: Ed. Revan, 2012. 189 p. (in Portuguese)

Martínez-Blanco, J.; Colón, J.; Gabarrell, X.; Font, X.; Sánchez, A.; Artola, A.; Rieradevall, J. The use of life cycle assessment for the comparison of biowaste composting at home and full scale. Waste Management, v.30, n. 6 , 2010, p.983-994.

Miller, F. C. Composting as a process base on the control of ecologically selective factors. In: METTING, F. B., Soil microbial ecology: application in agricultural and environmental management. New York, NY, Marcel Dekker Inc., p. 515 - 541, 1993.

Münnich, K.; Mahler, C. F.; Fricke, K. Pilot Project of mechanical-biological treatment of waste in Brazil. Waste Management (Elmsford), v. 26, n. 2 , 2006, p. 150-157.
Native Power (2013). Available in: <http://www.native-power.de>. Acess in: 12 mar. 2013.

Pain, J. (1972) Another kind of garden. Available in: <http://library. uniteddiversity.coop/Permaculture/Another_Kind_of_Garden-The_ Methods_of_Jean_Pain.pdf>. Acesso em: 24 fev. 2014.

Pires, A.; Martinho, G.; Ni-Bin, C. Solid state manegement in European countries. A review of systems analysis techniques. Journal of Environmental Manegement, v.92, n. 4, 2011, p.1033-1050.

Rose, J. L.; Mahler, C.f.; Izzo, R. L. S. Comparison of the methane oxidation rate in four media. Revista Brasileira de Ciência do Solo (Printed), v. 36, 2012, p. 803-812.

Randle, J; Flegg, M. Oxygen measurements in a Mushroom Compost Stack. Scientia horticulae. v.8, n. 4, 1978, p. 315-323.

Sokal, R. R.; Rohlf, F. J. Biometry: The principles and practice of statistics in biological research. 4.ed. W. H. Freeman and Co, 2012. 937p.

Standard Methods. Standard Methods for the examination of water and wastewater, Method D 5220 Chemical Oxygen Demand (COD), 1997.

Teixeira, L.b.; Germano, V.I.c; Oliveira, R.f. De; Furlan Junior, J. Composting process from urban organic waste into static windrow with natural ventilation. Belém: Embrapa Amazônia Oriental, 2004. 7p. (Embrapa Amazônia Oriental. Circular Técnica, 33). (in Portuguese)

USEPA - United States Environmental Protection Agency. Environmenta regulation and technology control of pathogens and vector attraction in sewage sludge. Under 40 CRF. Part 503. EPA-625/R-92/013, 1992. Available in: < http://water.epa.gov/scitech/wastetech/biosolids/upload/2007_05_31_625r92013_625R92013.pdf >. Acesso em: 19 mai. 2013.

USEPA- United States Environmental Protection Agency. Landfill gas emissions model (LandGEM) version 3.02 user's guide. Washington: Office of Research and Development, EPA-600/R-05/047, 2005. 48p.

Viana, T.a.p. Analysis of the methane emission estimates for landfills in CDM projects in Brazil. Dissertation (MSc) - 2011 State University of Rio de Janeiro, Faculty of Engineering. (in Portuguese).

Zuokaite, E.; Zigmontiene, A. Application of a natural cover during sewage sludge composting to reduce gaseous emissions. Polish Journal of Environmental Studies, v.22, n.2, 2013, p.621-626. 